\title{
PROCEEDINGS
}

OF THE

\section{American Society of}

International Law

AT ITS

FIFTY-SIXTH ANNUAL MEETING

HELD AT

WASHINGTON, D. C.

APRIL 26-28, 1962

PUBLISHED BY THE SOCIETY

2223 Massachusetts Avenue, N.W.

WASHINGTON 8, D. C.

1962 
CoPYRIGHT (C) $1962 \mathrm{BY}$

THE AMERICAN SOCIETY OF INTERNationaL LAW

It is the policy of the American Society of International Law not to take an official position, by resolution or otherwise, upon controversial questions. The views expressed in the addresses and remarks delivered at its annual meetings and appearing in its printed PROCEEDINGS are those of the individual speakers and are not to be taken as representing the views of the Society.

LANCASTER PRESS, INC.

LANCASTER, PA. 


\section{TABLE OF CONTENTS}

OfFicers AND CoMmittees FOR the YeAR 1962-1963 .......... vi

Incorporation Act of September $20,1950 \ldots \ldots \ldots \ldots \ldots \ldots$ viii

Resolution of April $28,1951 \ldots \ldots \ldots \ldots \ldots \ldots \ldots \ldots \ldots \ldots \ldots$ xi

Constitution of the American Society of International Law .... xii

Regulations of the Society $\ldots \ldots \ldots \ldots \ldots \ldots \ldots \ldots \ldots \ldots \ldots \ldots \ldots$

\section{First Session}

Thursday, April 26, 1962, at 2:30 P.M.

Panel I: Disarmament

Address, "Enforcement of Disarmament: The Problem of the Response," by Roger $D$. Fisher .................... 1

Comments :

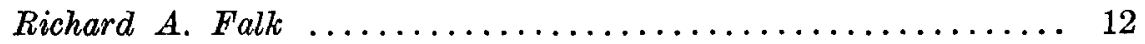

John T. McNaughton ......................... 13

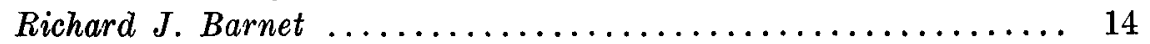

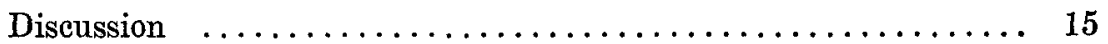

Reporter: Lee R. Marks

Panel II : The Antr-Trust Laws of the European EConomic Community

Address, "The Substantive Law of Article 85 (1) of the Rome Treaty -The Case of 'Exclusive Dealing,' "' by George Nebolsine ....... 18 Address, "The Anti-Trust Laws of the Common Market Countries," by Stefan A. Riesenfeld ....................... 27

Address, "Implementing the Anti-Trust Sections of the Rome Treaty,"

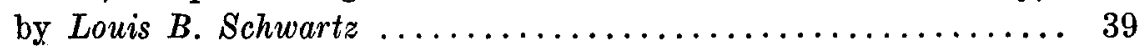

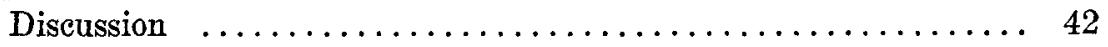

Reporter: Murray J. Belman

\section{Second Session}

Thursday, April 26, 1962, at 8:30 P.M.

Address by President Arthur H. Dean ................ 44 Address, "Observations on International Law in Underdeveloped Areas," by Francis Deak ..................... 54

\section{Third Session}

Friday, April 27, 1962, at 10:00 A.M.

\section{Business Meeting}

In Memoriam

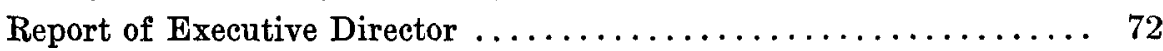


Reports of Committees:

PAGE

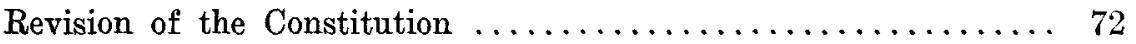

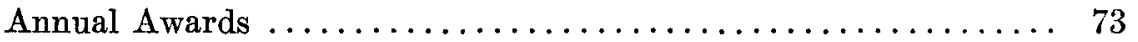

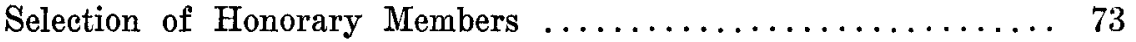

Publications of the Department of State and the United Nations .. 73

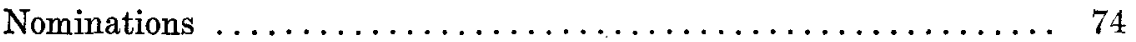

Resolution on Publications of the Department of State and the

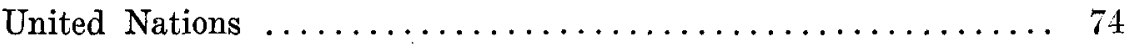

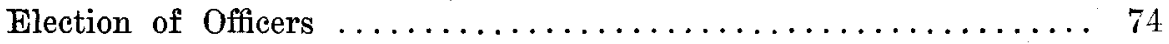

\section{Fourth Session}

Friday, April 27, 1962, at 2:30 P.M.

\section{Panel I : New Developments in Investment Guaranties}

Address, "The Investment Guaranty Program of the United States,"

by Seymour J. Rubin ....................... 77

Address, "International Investment Guaranties: Possibilities and

Problems," by Aron Broches .................... 81

Discussion .............................. 87

Reporter: Eliezer Ereli

\section{Panel II: The United Nations Program for the Codification and Progressive Development of International Law-A Critical Appraisal}

Address, "Selected Problems of the United Nations Program for the Codification and Progressive Development of International Law,"

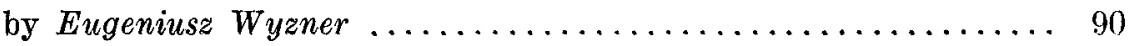
Address, "United Nations Contribution to Developing International

Law," by Ernest L. Kerley ...................... 99

Comments :

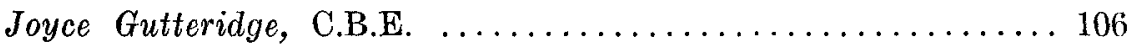

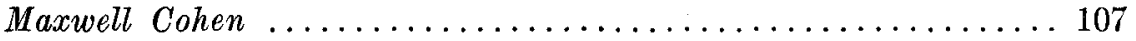

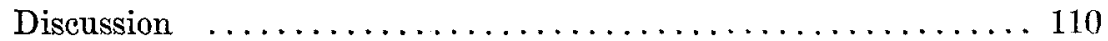

Reporter: Thomas T. F. Huang

\section{Fifth Session}

Friday, April 27, 1962, at 8:30 P.M.

International Aviation Policy: The Warsaw Convention, The Hague Protocol, and International Limitation of Liability

Address, "The Warsaw Convention Today," by Oliver J. Lissitzyn .. 115 Address, "Hiking the Limits of Liability at The Hague," by $G$.

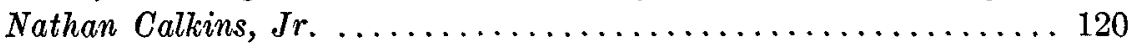


Address, "Limitation of Liability for Aircraft Accidents in International Transportation: The Warsaw Convention and the Hague Protocol,"' by Stanley D. Metzger ................ 128

Comments :

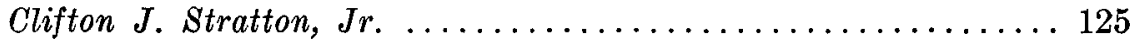

George Buschmann ............................ 128

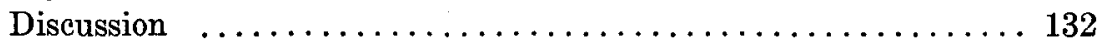

Reporter: Jerry C. Trippe

\section{Sixth Session}

Saturday, April 28, 1962, at' 10:00 a.M.

The New Foreign Trade Proposals: Their Implications for International Trade Co-operation

Remarks by the Honorable Nicholas deB. Katzenbach .......... 135

Address, "The Trade Expansion Act of 1962," by Robert Triffin . . . 139

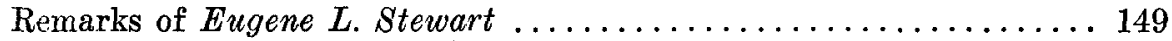

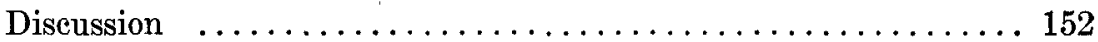

Reporter : Knute E. Malmborg, Jr.

Student Moot: Assessments Case, International Court of Justice

Judges : The Honorable Green H. Hackworth; John G. Laylin, Maxwell

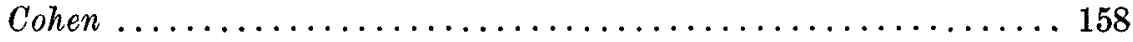

For the United States of America: Frederic Freilicher and Don Gellers, Columbia Society of International Law.

For Belgium: David Greenspan and James Rendall, Osgoode Hall Law School.

For the United Arab Republic: Stephen Doyle and William A. Kyler, Duke International Law Society.

\section{Annual Dinner}

Saturday, April 28, 1962, at $7: 00$ P.M.

Remarks of the Toastmaster $\ldots \ldots \ldots \ldots \ldots \ldots \ldots \ldots \ldots \ldots \ldots \ldots \ldots \ldots 171,172$

Address, "The United Nations Charter: 1945 and 1962," by His

Excellency, Mr. James Plimsoll, C.B.E. .............. 162

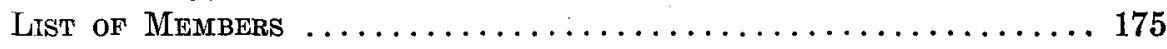

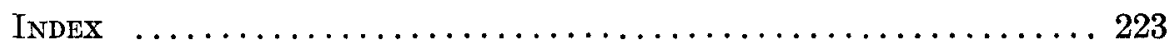

